\title{
New maternal line of the Cornish breed of the "Smena" selection and genetic center
}

\author{
Zh. V. Emanuylova ${ }^{1}, A . V$. Egorova ${ }^{1,2, *}$, D. N. Efimov ${ }^{2}$, and A.A. Komarov ${ }^{1}$ \\ ${ }^{1}$ SGC "Smena" - a branch of the Federal State Budgetary Scientific Institution Federal Scientific \\ Center "All-Russian Research and Technological Institute of Poultry" of the Russian Academy of \\ Sciences (FSC "VNITIP" RAS), Russia \\ ${ }^{2}$ FSBSI Federal Scientific Center "All-Russian Scientific Research and Technological Institute of \\ Poultry" of the Russian Academy of Sciences (FSC "VNITIP" RAS), Russia
}

\begin{abstract}
The article is devoted to the assessment of the selection effect of the new line CM6. It was found that the five-year selection of meat hens of this line resulted in their egg production increase by 15.5 and $1.25 \%$ in 30 and 60 weeks of life (2020). The increase in the yield of hatching eggs, their fertilization, hatching of chickens and the yield of chickens per 1 hen was $1.4 ; 1.1 ; 1.7 ; 5.1 \%$, respectively. The live weight of 5 -week-old young birds is increased both for cockerels and hens by $10.2-8.7 \%$; enhanced muscularity of the chest and legs at this age by $2.7-2.6 \%$ and $5.6-$ $5.7 \%$; increased feed conversion by $3.3-2.5 \%$ (2020) pursuant to gender. The integrated indicator - the productivity index of broilers of the combination CM5679 in 2020 was 389 units, which is $25.5 \%$ higher than in 2016. The productivity of meat hens of the mother line of the Cornish CM6 breed is high, the bird is competitive.
\end{abstract}

\section{Introduction}

Poultry farming is one of the most dynamically developing sectors of livestock farming on a global scale, playing an important role in the production of animal protein, which is the most important component of human nutrition.

In recent years, broiler production has been developing at a rapid pace, highly productive crosses of meat hens have been created, breeding programs are being enhanced [1-4, 6-10].

The similarity between individuals of the same species, as well as the greater similarity of descendants with their parents than with other individuals of a given species, indicates the existence of a hereditary relationship between generations. In general, this relationship is ensured through the transfer of genetic information, which represents, as it were, a plan for the development of the structure and functions of the future organism, received from the reproductive cells of the parents [1].

\footnotetext{
${ }^{*}$ Corresponding author: egorova@vnitip.ru
} 
These programs envisage not only selection for increasing the genetic potential for live weight gain, feed conversion, fleshing of the chest, legs, meat qualities of broilers, as well as reproductive qualities of poultry [1,2].

A comprehensive assessment of broiler crosses depends on the number of broilers obtained from one layer of the breeder flock. Therefore, the selection of maternal parental forms to enhance reproductive qualities is necessary [2,4].

Intensive breeding of meat hens, especially in Cornish lines, for growth rate and breast flesh has led to a significant increase in the efficiency of broiler production worldwide. However, this progress was accompanied by negative trends: a decrease in the level of signs associated with reproduction, as well as the appearance and increase in the frequency of metabolic abnormalities of growth and development - ascites, sudden death syndrome.

In recent years, in breeding work, much attention is paid to methods of genomic selection, in particular, the use of color - and feathersex birds [2,5,22,23].

The research is aimed to evaluate the effect of breeding a new maternal line of the Cornish cross "Smena 9" in the production.

\section{Materials and methods}

The work was performed on the poultry of the original line CM6 and combinations: CM56 and CM5679 in production conditions of SGC "Smena".

The enterprise uses a combined selection method. The breeding nest was formed on the basis of 13 hens and 1 cockerel, their number was 60. 105-198 birds of offspring were taken from one cockerel, 8-15 birds from one laying hen. Poultry line CM6 (breeding group) was completed from broodstock homozygous for the rapid feathering gene, considering the main economically significant traits (live weight, fleshing of the chest, legs, payment for feed, egg production, egg weight, hatchability).

The accounting of the main indicators (live weight, egg production, egg weight, sexual maturity, fleshing of the chest, legs, feed conversion for selection poultry is individual [6].

Feathering of day-old chicks was determined by the phenotype: cover feathers are longer than flight feathers or equal to them (slow feathering), cover feathers are shorter than flight feathers and well developed (fast feathering).

At SGC Smena, 35-day-old cockerels, selected with the best indicators of live weight and meat body shape, are placed in cages for individual registration of feed conversion. From 36 to 42 days for each cockerel, feed consumption is considered, then they are weighed and feed costs $\mathrm{kg} / \mathrm{kg}$ are calculated. In further breeding work at the enterprise, producers with a high live weight and feed conversion are used.

The bird was kept on a deep bed of coniferous sawdust, natural mating was used, and feeding was performed considering the recommendations of VNITIP [24].

To determine the meat qualities of the final hybrid, the carcasses were cut pursuant to the method [25].

\section{Results and discussion}

The egg production of chickens for 30 and 60 weeks of life of the CM6 line in 2020 is higher than in 2016 by 15.5 and $1.2 \%$, respectively, by age (tab. 1) 
Table 1. Poultry productivity of the CM6 line.

\begin{tabular}{|c|c|c|c|c|}
\hline \multirow[b]{2}{*}{ Indicator } & \multirow{2}{*}{$\begin{array}{l}\text { Gen } \\
\text { der }\end{array}$} & \multicolumn{2}{|c|}{ Year } & \multirow{2}{*}{$\begin{array}{c}2020 \\
\text { by } \\
2016, \\
\%\end{array}$} \\
\hline & & 2016 & 2020 & \\
\hline $\begin{array}{r}\text { Egg production by laying hen, pcs.: } \\
\text { in } 30 \text { weeks of life } \\
\text { in } 60 \text { weeks of life }\end{array}$ & & $\begin{array}{l}18.1 \pm 0.573 \\
121.4 \pm 1.07 \\
\end{array}$ & $\begin{array}{l}20.9 \pm 0.415 \\
122.9 \pm 1.03 \\
\end{array}$ & $\begin{array}{r}+15.5 \\
+1.2 \\
\end{array}$ \\
\hline $\begin{array}{r}\text { Egg mass of chickens }(\mathrm{g}) \text { at the age: } \\
30 \text { weeks } \\
52 \text { weeks }\end{array}$ & & $\begin{array}{c}58.7 \pm 0.13 \\
69.49 \pm 0.320\end{array}$ & $\begin{array}{c}59.4 \pm 0.10 \\
69.95 \pm 0.240\end{array}$ & $\begin{array}{l}+1.2 \\
+0.7\end{array}$ \\
\hline Hatchery egg yield, $\%$ & & 93.3 & 94.7 & +1.4 \\
\hline Fertility of eggs, $\%$ & & 91.7 & 92.8 & +1.1 \\
\hline Chick hatching (individual), $\%$ & & 75.7 & 77.4 & +1.7 \\
\hline Output of chickens on 1 laying hen, birds & & 85.7 & 90.1 & +5.1 \\
\hline Hen preservation, $\%$ & & 98.0 & 98.7 & +0.7 \\
\hline \multicolumn{5}{|l|}{ Live weight: } \\
\hline \multirow[b]{2}{*}{1 week, $g$} & $0^{2}$ & $236.0 \pm 0.440$ & $240.0 \pm 0.420$ & +1.7 \\
\hline & क & $229.0 \pm 0.390$ & $237.0 \pm 0.405$ & +3.5 \\
\hline \multirow[b]{2}{*}{5 weeks, $\mathrm{kg}$} & $0^{1}$ & $2.360 \pm 0.007$ & $2.600 \pm 0.004$ & +10.2 \\
\hline & क & $2.070 \pm 0.006$ & $2.250 \pm 0.003$ & +8.7 \\
\hline \multicolumn{5}{|l|}{ Muscularity, score: } \\
\hline \multirow{2}{*}{ chest } & $\hat{0}$ & $4.53 \pm 0.007$ & $4.65 \pm 0.005$ & +2.7 \\
\hline & क & $4.58 \pm 0.006$ & $4.70 \pm 0.004$ & +2.6 \\
\hline \multirow[b]{2}{*}{ feet } & $0^{\pi}$ & $2.15 \pm 0.002$ & $2.27 \pm 0.001$ & +5.6 \\
\hline & क्+ & $2.10 \pm 0.001$ & $2.22 \pm 0.002$ & +5.7 \\
\hline \multirow{2}{*}{$\begin{array}{l}\text { Feed conversion, } \mathrm{kg} / \mathrm{kg} \text {, for a period of } 1-35 \\
\text { days }\end{array}$} & $\hat{0}^{1}$ & $1.55 \pm 0.012$ & $1.50 \pm 0.010$ & -3.3 \\
\hline & क & $1.59 \pm 0.015$ & $1.55 \pm 0.017$ & -2.5 \\
\hline Preservation of young birds, $\%$ & & 97.1 & 97.6 & +0.5 \\
\hline
\end{tabular}

The weight of eggs at 30 and 52 weeks increased in 2020 along this line by 1.2 and $0.7 \%$, respectively, for age. The hatching egg yield was high and ranged within 93.3 $94.7 \%$. The chick yield per layer in 2020 was $5.1 \%$ higher than in 2016 . The survival rate of adult birds during the productive period was high and amounted to $98.0 \%$ (2016) and $98.7 \%(2020)$.

As a result of five-year selection, the live weight of young birds in the first week increased by $1.7 \%$ for cockerels and $3.5 \%$ for chickens; and at 5 weeks of age - by $10.2-$ $8.7 \%$, respectively, gender. As for the fleshing of the chest and legs, this indicator enhanced in 2020 by $2.7-2.6 \%$ and $5.6-5.7 \%$, respectively, for the indicator and gender. The feed conversion is increased by $3.3-2.5 \%$. The survival rate of the young is high and ranged from 97.1 to $97.6 \%$.

To obtain a two-line form of CM56, the cockerels of the paternal line CM5 are crossed with hens of the maternal line CM6.

The scheme for obtaining broilers is as follows:

ふึ่ CM56 X 우 CM79

Chickens CM79 - maternal parental form. 
The bird of the paternal parental form CM56 is of the meat type, the Cornish breed, in which the high live weight of the CM5 line bird and the higher reproductive qualities of the CM6 line are combined.

Table 2 shows the data characterizing the cockerels of the cockerel parental form CM56 in comparison with linear cockerels CM5 and CM6.

Table 2. Economically useful qualities of two-line CM56 cockerels.

\begin{tabular}{|c|c|c|c|c|c|}
\hline Sign & CM5 & CM6 & CM56 & $\begin{array}{c}\text { CM56 to } \\
\text { CM5, \% }\end{array}$ & $\begin{array}{c}\text { CM56 to } \\
\text { CM6, \% }\end{array}$ \\
\hline Fertility of eggs, \% & 91.4 & 9.4 & 94.3 & +2.9 & +1.9 \\
\hline Chick hatching, \% & 74.9 & 76.8 & 83.5 & +8.6 & +6.7 \\
\hline Preservation, \% & & & & & \\
- aoung birds adult & 97.0 & 97.5 & 9.7 & +0.7 & +0.2 \\
- & 9.7 & 97.8 & +0.3 & +0.1 \\
cockerels & & & & \\
\hline
\end{tabular}

Two-line cockerels CM56 have an advantage over single-line cockerels in terms of the considered characteristics (egg fertilization, hatching of chickens, poultry safety). When compared with the parameters of the CM5 line, the difference was 2.9 and $8.6 \%$ and that of the CM6 line -1.9 and $6.7 \%$, respectively. The survival rate of young and adult SM56 cockerels was 97.7 and $97.8 \%$, which is slightly higher than for the same parameters of the CM5 line by 0.7 and $0.3 \%$ and the CM6 line - by 0.2 and $0.1 \%$.

The new paternal form CM56 (cross "Smena 9") surpasses the bird B56 (cross "Smena 8 ") in survival rate by 0.7 and $0.5 \%$ (97.6\% versus $96.9 \%$ - young birds and $97.9 \%$ versus $97.4 \%$ - adult cockerels), egg fertilization - by $3.3 \%$ (94.5 and 91.2\%) and chick hatching by $5.3 \%(83.5$ and $78.0 \%)$.

Table 3. The results of testing broilers with the combination of CM5679 in the SGC "Smena".

\begin{tabular}{|l|c|c|c|}
\hline \multirow{2}{*}{ Indicator } & \multicolumn{2}{|c|}{ Year } & \multirow{2}{*}{$\begin{array}{l}2020 \text { by } \\
2016, \%\end{array}$} \\
\cline { 2 - 4 } & 2016 & 2020 & +3.3 \\
\hline Chick hatching,\% & 81.0 & 84.3 & +13.5 \\
\hline Live weight at 5 weeks, g & 2009 & 2281 & +1.2 \\
\hline Preservation, \% & 97.4 & 98.6 & +8.3 \\
\hline $\begin{array}{l}\text { Feed costs per 1 kg of live weight } \\
\text { gain, kg }\end{array}$ & 1.80 & 1.65 & +1.3 \\
\hline $\begin{array}{l}\text { The output of the pectoral muscles } \\
\text { in\% of live weight }\end{array}$ & 21.0 & 22.5 & +25.5 \\
\hline Broiler productivity index, units & 310 & 389 & \\
\hline
\end{tabular}

Broilers of the combination CM5679, when tested in production conditions of the SGC "Smena" in 2020, had the best performance in terms of chick hatching, live weight at 5 weeks of age, safety, feed costs, breast muscle yield in \% to live weight, productivity index by $3.3 ; 13.5 ; 1.2 ; 8.3 ; 1.3 ; 25.5 \%$ compared to 2016 (Table 3 ).

\section{Conclusions}

It was found that the egg production of chickens of the CM6 maternal line at 30 and 60 weeks of life in 2020 was higher by 15.5 and $1.25 \%$, respectively, by age compared to 2016. 
The increase in the yield of hatching eggs, their fertilization, hatching of chickens, and the yield of chickens per 1 laying hen in 2020 was $1.4 ; 1.1 ; 1.7 ; 5.1 \%$ compared to these indicators in 2016, respectively.

The live weight of 5-week-old young birds in 2020 increased both for cockerels and chickens by $10.2-8.7 \%$; enhanced muscularity of the chest and legs at this age by $2.7-2.6 \%$ and $5.6-5.7 \%$; increased feed conversion by $3.3-2.5 \%$ compared to 2016 , pursuant to gender.

The complex indicator - the productivity index of broilers of the combination CM5679 in 2020 amounted to 389 units, which is $25.5 \%$ higher than in 2016.

The productivity of meat hens of the mother line of the Cornish CM6 breed is high, the bird is competitive.

\section{References}

1. I. L. Galpern, A.V. Sinichkin, O. I. Stashevskaya, et al., Breeding and genetic methods and programs for breeding new lines and creating competitive crosses of egg and meat hens, 163 (2010)

2. L. I. Tuchemsky, K.V. Zlochevskaya, V. I. Fisinin, G. V. Gladkova, The Selection of Broiler Chicken at State breeding Farm" Smena", 308 (2008)

3. A.V. Egorova., L. I. Tuchemsky, Zh. V. Emanuylova, D. N. Efimov, Zootechny, 6(2), 4 (2015)

4. L. S. Karpenko, The advancement of Plymouth Rock chicken carrying the gene of slow feathering, Proceedings of III International Conference "Poultry Production-World and Domestic Experience", 99 (2015)

5. T. Petrukovich, Animal Husbandry of Russia, 12(11), 12 (2017)

6. Ya. S. Roiter, A. V. Egorova, A. P. Konopleva, et al., Selection and breeding work in poultry, 287 (2016)

7. B. Carre, B. Meda, H. Juin, Progress in broiler selection: benefits, limitations as assessed by the didestive function, and consequence of dietary lysine concentration, Proc. XIV Eur Poultry Conf., 189-209(2014)

8. S. Cherepanov, O. Stanishevskaya, Preservation and usage of genetic resources in farm poultry, The Proc. XXV World's Poultry Cong., 343 (2016)

9. L. Lu. Dnutriev, O. Stanishevskaya, N. Dementyeva, Y. Turlova, M. Lapa, The Proc. XXV World's Poultry Cong., 345 (2016)

10. O. W. Willems, S. P. Miller, B. J. Wood, World's Poultry Science J., 69(1), 77-78 (2013)

11. D. N. Efimov, Zh. V. Emanuylova, E. V. Zhuravleva, A. V. Egorova, V. I. Fisinin, Agricultural Biology, 53, 1162-1168 (2018)

12. P. K. Bramwell, Sexing chicks in the backyard flock, The Poultry Site, http://www.the poultry site.com/

13. Y. H. Cheng, T. E. Kuo, D. N. Lee, C. F. Weng, Zoological Studies, 45, 104-113 (2006)

14. J. Zhao, J. Yao, F. Li, et al., Poultry Sci., 95(7), 1498-1503 (2016)

15. G. Bu, G. Huang, H. Fu, J. Li, S. Huang, Y. Wang, J. Mol. Endocrinol., 51, 261-276 (2013) 
16. L. Korshunova, Y. Royter, A. Egorova, The usage of gene modifiers in selection of new forms of color- and feather-sex poultry, Proc. XIV European Poultry Conf., 512 (2016)

17. Y. Royter, A. Egorova, A. Sevastianova, L. Korshunova, The selection of autosex interlinear forms of poultry (chicken, geese, Guinea fowl), Proc. XXV World's Poultry Congress, 257 (2016)

18. D. A. Dawson, S. Darby, F. M. Hunter, A. P. Krupa, I. L. Jones, T. A. Burke, Molecular Ecology Notes, 1(13), 201-204 (2001)

19. H. Ellegren Hens, EMBO Reports, 2(3), 192-196(2001)

20. H. Cerit, K. Avanus, Turk. J. Vet. Anim. Sci., 31(6), 371-374(2007)

21. H. Cerit, K. Avanus, World's Poultry Science J., 63(1), 91-99 (2007)

22. A.V. Egorova, L.V. Shakhnova, Poultry and poultry products, 3, 41-43 (2013)

23. T. Petrukovich, Animal Husbandry of Russia, 12, 11-12 (2017)

24. I. A. Egorov, V. A. Manukyan, T. M. Okolelova, et.al., Manual on Poultry Nutrition, 226 (2018)

25. V. S. Lukashenko, M. A. Lysenko, T. A. Stollyar, et al., Manual on the Anatomical Dressing, Organoleptic Evaluation of Poultry meat and Eggs, Egg Morphology, 35 (2013) 